\title{
Metals content in surface waters of an upwelling system of the northern Humboldt Current (Mejillones Bay, Chile)
}

\section{Abstract}

Physical-chemical parameters (temperature, salinity, dissolved oxygen, nutrients, and chlorophyll concentration) of surface waters were used to evaluate the influence of biological and physical processes over the metal concentrations $(\mathrm{Cd}, \mathrm{Ni}, \mathrm{V}, \mathrm{Mo}, \mathrm{Mn}$, and $\mathrm{Fe}$ ) in different periods of a normal annual cycle (June 2002 and April 2003), in Mejillones Bay (23 S), one of northern Chile's strongest upwelling cells. Two points were sampled every 2 months, but statistical analysis of these parameters did not show any spatial differences in surface water composition (annual average) in this bay. The order of total and dissolved metals by abundance (annual mean) in the Mejillones Bay surface waters during the sampling period was $\mathrm{Cd}<\mathrm{Ni}<\mathrm{Mn}<\mathrm{Fe}<\mathrm{V}<\mathrm{Mo}$.

The surface concentration of metals does not appear to be explained by anthropogenic inputs (at least not during the year of this work), and variability observed in this study appears to be natural. The lack of correlation between physical-chemical parameters and metals could indicate a more complex combination of factors acting on surface concentrations. Moreover, the mixture of water masses and the Oxygen Minimum Zone which characterizes the Mejillones bay should have an important influence on surface distribution of trace metals and can explain the high temporal variability observed in most of the metals analyzed in this work. A two-box conceptual model is proposed to suggest possible influences on metals in surface waters of this coastal ecosystem.

C 2007 Elsevier B.V. All rights reserved.

Keywords: Trace metals; Upwelling; Humboldt system; Marine surface water

\section{Introduction}

The continental margin is a boundary where several sources may affect the chemical characteristics of the

\footnotetext{
* Corresponding author. Tel.: +56 55 637865; fax: +56 55637804 .

E-mail addresses: jvaldes@uantof.cl (J. Valdés), droman@uantof.cl (D. Román), galvarez@uantof.cl (G. Alvarez), Luc.Ortlieb@bondy.ird.fr (L. Ortlieb),mguinez@uantof.cl (M. Guiñez).
}

water and bring contaminating materials. Of these, the 32 most important are continental sources (atmospheric 33 transport, river runoff), marine (upwelling), and diage- 34 netic exchanges at the water-sediment interface. These 35 sources provide organic and inorganic materials that 36 play an important role in biogeochemical cycles. For 37 example, nutrients and trace metals are essential to the 38 ecosystem, but should be carefully monitored because 39 they are potential contaminants in the coastal environ- 40 ment (Cotte-Krief et al., 2000). In both cases, and in the 41 
absence of contamination processes, upwelling is the principal source of surface nutrients and trace metals from the deep ocean.

In general, all metals present in marine waters are in dissolved and particulate forms. Many of these trace metals are classified as micronutrients because they are essential for phytoplankton growth. Most are components of the enzyme system, which catalyzes important biochemical reactions such as glycolysis, photosynthesis, and protein metabolism. Partitioning between dissolved and particulate forms of trace metals depends on the physical and chemical conditions of the marine environment and the nature of each metal (Libes, 1992). Moreover, any metal can assume various chemical forms, being able to form a wide variety of ions, compounds, or complexes, or being associated with different mineralogical or organic phases (Grotti et al., 2001). The concentration of these metals can be variable as a consequence of changing inputs and/or seasonal effects involving biological, geochemical, and physical interactions (Hatje et al., 2001).

Knowledge of the biogeochemical cycle of trace metals in coastal environments is needed in order to identify pollution sources and to explore biological and dynamical processes.

This paper aims to study the influence of biological and physical processes over the some metals content in different periods of a normal annual cycle, in surface waters of one the most productive coastal systems of northern Chile.

\subsection{Regional setting}

The Humboldt Current is one of the most productive 73 systems in the world. In the northern section of this 74 system, many permanent upwelling cells support im- 75 portant pelagic fisheries (Strub et al., 1998). Punta 76 Angamos and Mejillones Bay (Fig. 1) form the most 77 productive upwelling system of northern Chile. Many 78 studies concerning biological and physical characteris- 79 tics of this system have been developed in recent years, 80 improving our understanding about their response to 81 ocean-climatic variability, principally, El Niño events 82 (Escribano et al., 1998; Gonzalez et al., 1998, 2000; 83 Iriarte et al., 2000; Sobarzo and Figueroa, 2001; Ulloa 84 et al., 2001; Pizarro et al., 2002; Gonzalez et al., 2004; 85 Iriarte and Gonzalez, 2004). This area borders one of the 86 world's most arid regions, and continental input to the 87 ocean is restricted to minor atmospheric transport of 88 lithogenic particles (Vargas et al., 2004). For this reason, 89 upwelling seems to be one of the most important pro- 90 cesses influencing the chemical composition of the sur- 91 face waters. Mejillones Bay is a hotspot of biological 92 productivity. This bay is considered an upwelling 93 shadow system (UPS), which responds with more 94 intense biological productivity due to its internal thermal 95 stability (Marín and Olivares, 1999; Marín et al., 2003). 96 Studies of the Mejillones Bay have been, principally, 97 focused on the structure and composition of marine 98 sediments and their potential for paleo-ocean-climatic 99 reconstructions of the last millennia (Ortlieb et al., 2000; 100

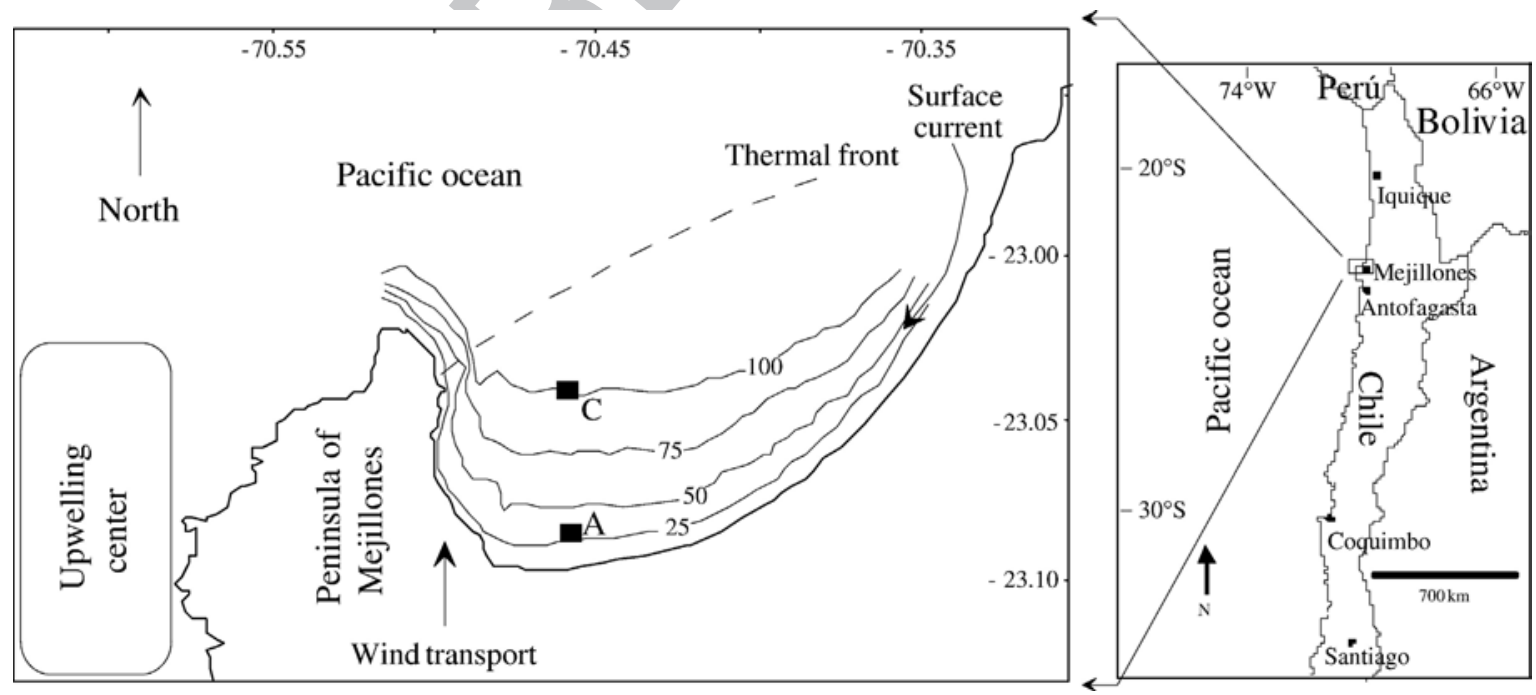

Fig. 1. Oceanographic setting of Mejillones Bay, showing schematic location of upwelling cell and location of sampling stations: A is coastal and C pelagic. Bathymetry's lines each $25 \mathrm{~m}$ are showed. The dashed line represents the position of the thermal front, which generates an upwelling shadow (UPS) in Mejillones Bay (Marín et al. 2003). 
Valdés et al., 2000; Valdés and Ortlieb, 2001; Valdés et al., 2003, 2004; Vargas et al., 2004). As part of the latest studies, redox-sensitive metals preserved in sediments have been analyzed in order to calibrate proxies of paleoxygenation (Valdés, 2004) and to asses potential problems of marine contamination derived from intense industrial development in recent years (Valdés et al., 2005).

Industrial activity in the area is represented by aquaculture and the fishmeal industry, power thermoelectric generation, and mineral exports. The real impact of this recent development on the marine ecosystem is still unknown.

\section{Materials and methods}

\subsection{Sample collection}

Surface water samples were collected from two sites in Mejillones Bay (Fig. 1), using clean, 51 inert sampling bottles (Niskin, General Oceanic) hung on stainless steel hydrowire. Between June 2002 and April 2003, samples for nutrients, chlorophyll- $a$, temperature, dissolved oxygen and salinity were collected monthly, while samples for trace metals were collected every 2 months. Samples were stored at low temperatures, in high density polyethylene bottles treated with nitric acid. Temperature, salinity, and dissolved oxygen data were collected with a CTD (Sea Bird, 19 plus) at the same sampling locations.

\subsection{Analytical procedures}

\subsubsection{Trace metals}

For dissolved concentrations, the samples were filtered with $0.45 \mu \mathrm{m}$ Millipore membranes in Nalgene Polisulfone (PSF) systems and acidified to $\mathrm{pH} 2$ with nitric acid. This was done the same day as the collection in a "clean laboratory environment", inside a laminar flow hood (Labconco, Purifier Class II). The samples were maintained at $4{ }^{\circ} \mathrm{C}$ inside the hood. Immediately before the ICP-OES measurements, the samples were acidified to $1 \mathrm{M}$ with $\mathrm{HNO}_{3}$.

For total concentrations, whole water samples were acidified to $\mathrm{pH} 2$ with nitric acid, and then a $250 \mathrm{ml}$ sub sample was digested with $20 \mathrm{ml}$ of nitric acid at $90{ }^{\circ} \mathrm{C}$ in a BOD bottle for $2 \mathrm{~h}$ in a stainless steel air forced oven (WTC Binder); the final acidity of this medium was $1 \mathrm{M}$ $\mathrm{HNO}_{3}$.

$\mathrm{Fe}$ and Mo were determined according to the method described by Román et al. (2003). Fe was measured with Hydraulic High Pressure Nebulization, Flame Furnace,
Atomic Absorption Spectrometry (HHPN-FF-AAS) 148 before off-line separation and preconcentration with 149 ammonium pyrrolidine dithiocarbamate (APDC) and 150 extraction with methyl isobutyl ketone (MIBK). Mo was 151 measured with Hydraulic High Pressure Nebulization, 152 Atomic Absorption Spectrometry (HHPN-AAS) before 153 off-line separation and preconcentration with MIBK; 154 afterwards, the sample was acidified to $7 \mathrm{M}$ with $\mathrm{HCl} .155$

$\mathrm{V}$ and $\mathrm{Mn}$ were determined by Inductively Coupled 156 Plasma, Optical Emission Spectrometry (ICP-OES) ac- 157 cording to the matrix matching technique, using purified 158 seawater (PSW) (1) for blank measurements and the 159 preparation of the standards for optimization and 160 calibration.

Ni was determined by adsorptive accumulation of the 162 respective complex with dimethylglyoxime at the drop 163 mercury electrode (DME) by Adsorptive Differential 164 Pulse Polarography (AdDPP) (2), and Cd was measured 165 by Potentiometric Stripping Analysis (PSA) in the 166 derivate signal mode $(3,4)$.

CASS - 4 (coastal seawater) and NASS - 4168 (oceanic seawater) certified reference seawater from the 169 Canadian National Research Council (NRC-CNRC) 170 were used to validate the techniques and for quality 171 control of the analytical determinations of $\mathrm{Mn}, \mathrm{Fe}, \mathrm{Ni}, 172$ Cd, and Mo. Vanadium's quality control was done with 173 the spiking technique. Purified coastal seawater (PSW) 174 was prepared with an additional solid phase extraction 175 step, using $\mathrm{C}_{18} 3 \mathrm{M}$ Empore Bakerbond (J. T. Baker) 176 discs (1) to improve the uptake of residual trace metals, 177 and was used for blanks, the ICP-OES calibration ma- 178 trix, with spikes as a secondary reference material for 179 quality control.

Before each series of ten measurements routine 181 controls of precision and accuracy were done. If, in four 182 consecutive tests, the precision varied from the expected 183 value by $20 \%$, all analytical procedures were reviewed, 184 and any having suspicious measurements were repeated. 185 When the committed relative error was $\geq 15 \%$ with 186 respect to the certified value, all the analytical pro- 187 cedures were reviewed, and any suspicions ones were 188 repeated.

All metal concentrations are expressed in $\mu \mathrm{g} 1^{-1}$.

\subsubsection{Nutrients and chlorophyll}

Water samples for nutrients were filtered through a 192 $0.45 \mu \mathrm{m}$ membrane filter and concentration was 193 determined using a Spectronic 20D Spectrophotometer, 194 according to methodology proposed by Parsons et al. 195 (1984). Chlorophyll- $a$ was measured in a Shimadzu RF- 196 5301 Spectrofluorometer, after filtering samples in the 197 dark through a $0.45 \mu \mathrm{m}$ membrane filter, following 198 
t1.1

$\mathrm{t} 1.2$

$\mathrm{t} 1.3$

t1.4

$\mathrm{t} 1.5$

$\mathrm{t} 1.6$

$\mathrm{t} 1.7$

t1.8

t1.9

t1.10

t1.11

t1.12

$\mathrm{t} 1.13$

t1.14

t1.15

t1.16

t1.17

$\mathrm{t} 1.18$

t1.19

t1.20

t1.21

$\mathrm{t} 1.22$

$\mathrm{t} 1.23$

t1.24

$\mathrm{t} 1.25$

199

200

Table 1

Descriptive statistics of all parameters measured in this work

\begin{tabular}{|c|c|c|c|c|c|c|c|}
\hline \multirow{2}{*}{\multicolumn{2}{|c|}{ Parameter }} & \multicolumn{2}{|l|}{ Mean } & \multicolumn{2}{|l|}{ SD } & \multicolumn{2}{|l|}{ Range } \\
\hline & & ST. A & ST. C & ST. A & ST. C & ST. A & ST. C \\
\hline \multicolumn{2}{|c|}{ Temperature $\left({ }^{\circ} \mathrm{C}\right)$} & 17.02 & 17.04 & 1.79 & 1.56 & $14.47-19.92$ & $15.18-20.06$ \\
\hline \multicolumn{2}{|c|}{ Salinity (psu) } & 34.79 & 34.77 & 0.11 & 0.10 & $34.64-34.98$ & $34.65-34.98$ \\
\hline \multicolumn{2}{|c|}{ Dis. Oxygen $\left(\mathrm{ml} \mathrm{l}^{-1}\right)$} & 6.40 & 7.24 & 2.31 & 2.02 & $2.22-10.47$ & $3.20-10.68$ \\
\hline \multicolumn{2}{|c|}{ Nitrate } & 2.13 & 1.04 & 2.95 & 1.15 & $0.06-8.70$ & $0.02-3.66$ \\
\hline \multicolumn{2}{|c|}{ Nitrite } & 0.11 & 0.08 & 0.14 & 0.07 & $0.00-0.46$ & $0.00-0.19$ \\
\hline \multicolumn{2}{|c|}{ Phosphate } & 1.40 & 1.13 & 0.74 & 0.49 & $0.20-2.70$ & $0.30-1.18$ \\
\hline \multicolumn{2}{|c|}{ Silicate } & 16.55 & 17.39 & 21.86 & 18.61 & $0.92-72.60$ & $0.00-50.50$ \\
\hline \multicolumn{2}{|c|}{ Chlorophyll- $a$} & 3.2 & 2.73 & 2.08 & 1.68 & $0.67-6.36$ & $0.24-5.31$ \\
\hline \multirow[t]{2}{*}{ V } & Total & 7.33 & 7.36 & 1.91 & 3.21 & $4.40-9.23$ & $3.48-12.80$ \\
\hline & Dissolved & 4.95 & 3.78 & 1.47 & 1.53 & $3.59-6.61$ & $2.11-6.39$ \\
\hline \multirow[t]{2}{*}{$\mathrm{Mn}$} & Total & 1.49 & 1.99 & 0.73 & 1.18 & $0.67-2.54$ & $0.87-4.09$ \\
\hline & Dissolved & 0.94 & 1.03 & 0.31 & 0.33 & $0.56-1.32$ & $0.56-1.38$ \\
\hline \multirow[t]{2}{*}{$\mathrm{Fe}$} & Total & 2.77 & 2.69 & 0.41 & 0.67 & $2.41-3.51$ & $1.96-3.58$ \\
\hline & Dissolved & 1.88 & 1.75 & 0.58 & 0.20 & $1.17-2.41$ & $1.57-2.11$ \\
\hline \multirow[t]{2}{*}{$\mathrm{Ni}$} & Total & 0.88 & 0.83 & 0.05 & 0.23 & $0.84-0.98$ & $0.36-0.98$ \\
\hline & Dissolved & 0.57 & 0.57 & 0.23 & 0.25 & $0.20-0.88$ & $0.21-0.82$ \\
\hline \multirow[t]{2}{*}{ Mo } & Total & 13.85 & 15.28 & 1.79 & 5.02 & $11.19-15.36$ & $9.43-21.74$ \\
\hline & Dissolved & 7.40 & 10.57 & 1.88 & 3.78 & $4.18-8.97$ & $5.73-15.44$ \\
\hline \multirow[t]{2}{*}{$\mathrm{Cd}$} & Total & 0.27 & 0.21 & 0.30 & 0.12 & $0.04-0.80$ & $0.10-0.39$ \\
\hline & Dissolved & 0.04 & 0.04 & 0.04 & 0.03 & $0.01-0.11$ & $0.01-0.07$ \\
\hline
\end{tabular}

$\mathrm{SD}=$ standard deviation; nutrients are expressed in $\mu \mathrm{mol}{ }^{-1}$; Chlorophyll is expressed in $\mu \mathrm{g} 1^{-1}$; metals are expressed in $\mu \mathrm{g} 1^{-1}$.

Holm-Hansen et al. (1965). The results of nutrients are reported as $\mu \mathrm{moll}^{-1}$; chlorophyll- $a$ is reported as $\mu \mathrm{gl}^{-1}$.

\subsection{Statistical analysis}

Temperature, dissolved oxygen, salinity, metals, nutrients, and chlorophyll were each analyzed by oneway analyses of variance (ANOVA), to test the significance of spatial and temporal variability. Pearson correlations and cluster analyses were performed to evaluate the relationships between all parameters measured at each station.

\section{Results and discussion}

\subsection{Statistical validation}

Descriptive statistics of all parameters measured in 211 both stations in Mejillones Bay are shown in Table 1.212 The comparison of these results with previous work in 213 this area (Rodriguez et al., 1991; Marín and Olivares, 214 1999; Marín et al., 2003) indicates that the sampling 215 period corresponds to a normal year, without influence 216 of El Niño event, which drastically changes water 217 column structure in this area.

Table 2

Spatial variability: one-way ANOVA of all parameters measured in Mejillones Bay

\begin{tabular}{lllllll}
\hline & Temperature & Oxygen & Salinity & Chlorophyll- $a$ & Nitrate & Nitrite \\
\hline$F$ & 0.000 & 0.75 & 0.14 & 0.31 & 1.18 & 0.39 \\
$P$ & 0.977 & 0.398 & 0.715 & 0.588 & 0.291 & 0.539
\end{tabular}

\begin{tabular}{cllllllll} 
& & & & & & & & \\
& Silicate & $\mathrm{V}_{\text {Total }}$ & $\mathrm{Mn}_{\text {Total }}$ & $\mathrm{Fe}_{\text {Total }}$ & $\mathrm{Ni}_{\text {Total }}$ & $\mathrm{Mo}_{\text {Total }}$ & $\mathrm{Cd}_{\text {Total }}$ & $\mathrm{V}_{\text {dissolved }}$ \\
\hline$F$ & 0.01 & 0.00 & 0.79 & 0.06 & 0.32 & 0.38 & $>0.26$ \\
$P$ & 0.927 & 0.986 & 0.396 & 0.812 & 0.587 & 0.553 & 0.621
\end{tabular}

\begin{tabular}{llllll} 
& $\mathrm{Mn}_{\text {dissolved }}$ & $\mathrm{Fe}_{\text {dissolved }}$ & $\mathrm{Ni}_{\text {dissolved }}$ & $\mathrm{Mo}_{\text {dissolved }}$ & $\mathrm{Cd}_{\text {dissolved }}$ \\
\hline$F$ & 0.27 & 0.26 & 0.00 & 3.39 & 0.01 \\
$P$ & 0.617 & 0.619 & 0.963 & 0.095 & 0.930 \\
\hline
\end{tabular}

$P<0.05$. 
Table 3

t3.2 Pearson's Coefficient Correlation of all parameters measured in Mejillones Bay

\begin{tabular}{lcclc}
\hline & Temperature & Oxygen & Chlorophyll & Nitr \\
\hline Oxygen & 0.53 & & & \\
Chlorophyll & 0.804 & & -0.651 & \\
Nitrate & -0.601 & & & 0.86 \\
Nitrite & & -0.7 & & \\
Phosphate & & -0.7 & -0.639 & \\
Silicate & & &
\end{tabular}

t3.10 $\mathrm{Mn}_{\text {tot }}$

0.822

t3.12 $\mathrm{Ni}_{\text {tot }}$

The results of the ANOVA showed no significant differences for oceanographic parameters between the two sampling stations (Table 2). In other words, the surface waters of Mejillones Bay, at averaged over a year, present homogeneous spatial conditions for all parameters measured. However, the results suggest some differences related to warm and cold periods which are characteristics of this zone.

Table 3 presents the results of Pearson's Coefficient of Correlation for all parameters measured in this study. In spite of number of parameters measured in this study, significant correlations were found in few cases. Only temperature and chlorophyll correlate with more than two other parameters.

\subsection{Oceanographic variability}

The annual mean surface temperature, salinity, and 234 dissolved oxygen levels found are characteristic of a 235 normal (non-El Niño) year, whereas the ranges of values 236 reflect seasonality and upwelling events influences. $\quad 237$

Considering the results of the ANOVA test, cluster 238 analysis was done with all physical-chemical parameters 239 combining both sampling stations. The result (Fig. 2) 240 showed a clear group formed by temperature, oxygen, and 241 chlorophyll, which present positive and significant 242 correlations, except in case of oxygen and chlorophyll 243 (Table 3). The others parameters didn't showed a clear 244 relationship, but nitrate-nitrite (significant correlation, 245

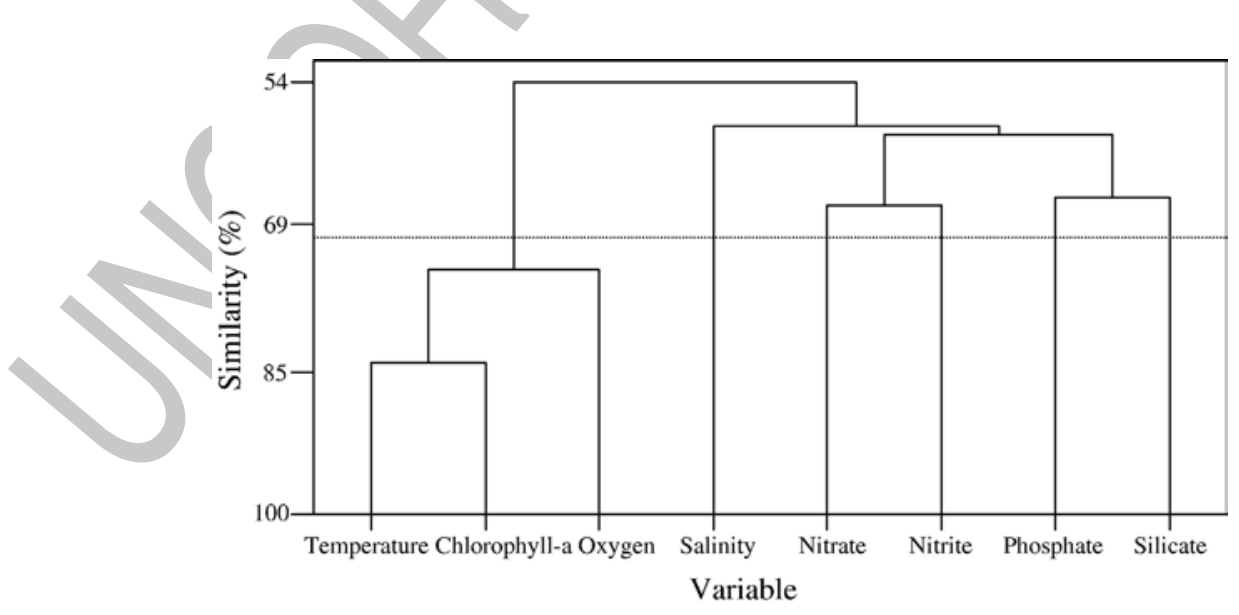

Fig. 2. Single-linkage dendrogram of similitude showing the results of clustering analyses of grouped physical-chemical parameters (not metals). The best line of similitude is shown. 
Table 3), and phosphate-silicate (no significant correlation) suggest some relationship (Fig. 2). Supported in these results we interpret that Mejillones Bay system presents two oceanographic scenarios: one characterized by a low influence of physical processes and rich nutrient surface waters (cold season) and another characterized by strong influences of physical processes coupled to biological factors (warm season), the last one represented in Fig. 2 by group formed by temperature, oxygen, and chlorophyll.

Temperatures ranged between $14.5{ }^{\circ} \mathrm{C}$ (winter) and $20.1{ }^{\circ} \mathrm{C}$ (summer) and dissolved oxygen between $2.2 \mathrm{ml}$ $\mathrm{1}^{-1}$ and $10.7 \mathrm{ml} \mathrm{l}^{-1}$ (both in summer; Table 1, Fig. 3). A considerable decrease of these parameters was registered in February. This situation suggests upwelled waters present inside the bay. At this month, it also registered an increase of phosphate (Fig. 3). The negative correlation between dissolved oxygen and phosphate has been used as an indicator of upwelling in this bay (Rodriguez et al., 1991).

During cold season (April-September) nutrients concentration is high because productivity is inhibited due to a lack of radiation. The low intensity of productivity generates low chlorophyll concentrations (Fig. 3). During warm season (October-March), when radiation is optimum, the productivity increases and, consequently, the nutrient concentrations decrease and chlorophyll increases (Fig. 3). A similar pattern, especially between nitrate and chlorophyll, was observed by Rodriguez et al. (1991), during 1987-88.

\subsection{Metal content in surface waters}

The concentrations of total and dissolved metals at each station are showed in Table 1. As was the case for oceanographic parameters, ANOVA did not show significant differences in metal concentrations between both sampling stations (Table 2). In order of abundance, the total and dissolved trace metals (annual mean) in the surface waters of Mejillones Bay (2002-2003) were $\mathrm{Cd}<\mathrm{Ni}<\mathrm{Mn}<\mathrm{Fe}<\mathrm{V}<\mathrm{Mo}$.

In general, metals in seawaters can be classified according to their interactive properties with biological and physical-chemical processes. Two groups can be identified: conservative and non-conservative. The first group, including Mo, presents few interactions with the biological cycle and its horizontal and vertical distribution is governed by physical processes such as advection and turbulent mixing (Libes, 1992). The second group, including $\mathrm{V}, \mathrm{Ni}, \mathrm{Cd}, \mathrm{Fe}$, and $\mathrm{Mn}$, is affected by biological processes, whether via scavenging and/or biological uptake (Brown et al., 1994). In the latter case, phytoplankton affects the distribution of dissolved 296 metals, using most of them as micronutrients (Gonzalez- 297 Davila, 1995). These intrinsic characteristics of metals 298 must be considered when interpreting this study's 299 results.

\subsubsection{Vanadium}

301

The predominant chemical form of $\mathrm{V}$ in oxic waters 302 is vanadate, $\mathrm{H}_{2} \mathrm{VO}_{4}^{-}$(Morford and Emerson, 1999), 303 whose behavior is mostly conservative with some 304 possible nutrient cycling (Bruland, 1983). Total and 305 dissolved V variability presents a general trend char- 306 acterized by high concentrations in cold season and low 307 concentrations in warm season, similar to nutrient 308 behavior. The partitioning between the dissolved and 309 particulate phases appears to be relatively constant 310 throughout the year with exception of February in 311 pelagic station (Fig. 3). This situation points to an 312 increase of the particulate form, which could be asso- 313 ciated to the influence of upwelled water transported 314 into the bay by onshore advection.

\subsubsection{Manganese}

$\mathrm{Mn}$ is present in oxic waters as $\mathrm{MnO}_{2}$ (Russell and 317 Morford, 2001). According to Kremling (1985) and 318 Libes (1992), this metal is enriched in coastal surface 319 waters due to a large metal supply from external sources. 320 Variability was more marked for total Mn than for its 321 dissolved form, which could be explained by the 322 presence of particulate $\mathrm{Mn}$ in surface waters during 323 periods of high total $\mathrm{Mn}$ concentrations (i.e. October). 324 According to Schenau et al. (2002), the most important 325 primary source of $\mathrm{Mn}$ to the ocean is the product of 326 continental weathering. Valdés et al. (2005) found a 327 significant correlation between this metal and $\mathrm{Al}$ in the 328 Mejillones Bay marine sediments, which is a signal of 329 lithogenic input. In Mejillones the continental transport 330 to the ocean is controlled almost exclusively by winds 331 (Vargas et al., 2004). The strongest winds from the south 332 and south-west develops during spring and summer 333 conditions (Escribano et al., 2004) mostly in Septem- 334 ber-October, which could to explain the increase of 335 particulate $\mathrm{Mn}$ registered in October.

\subsubsection{Iron}

The annual variation of $\mathrm{Fe}$ was different at each 338 sampling station. At the coastal station, both total and 339 dissolved iron concentrations were low in winter and 340 increased during spring-summer. On the other hand, the 341 pelagic station showed an opposite trend: high total 342 concentrations during winter and low total concentra- 343 tions during spring-summer, with constant dissolved 344 

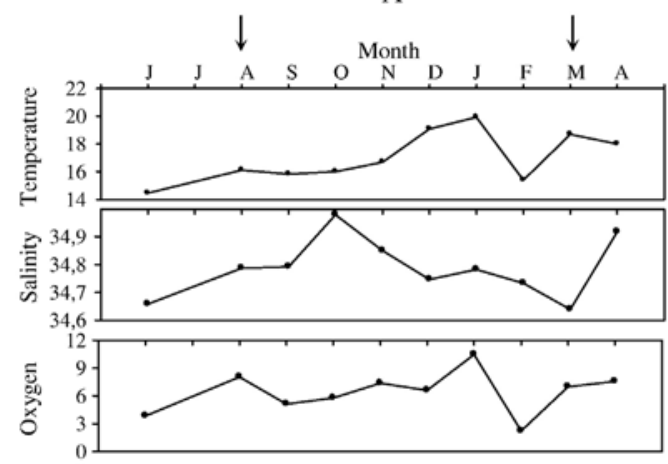

蒿
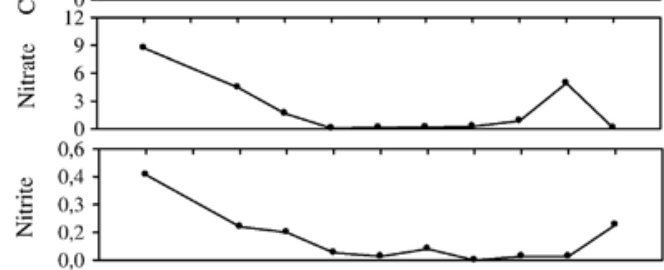

农
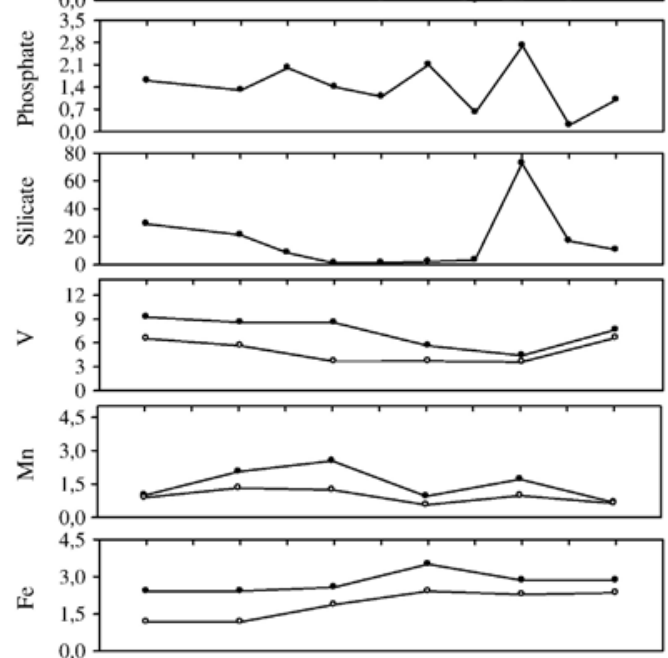

$$
\text { z }
$$

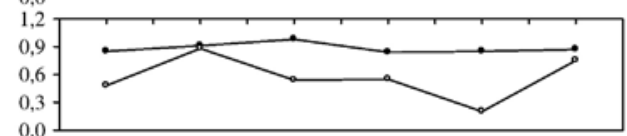

ํํㄴ
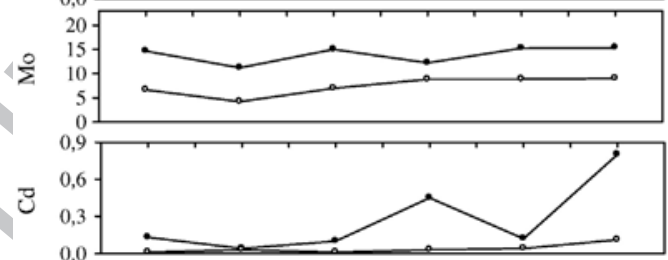

C
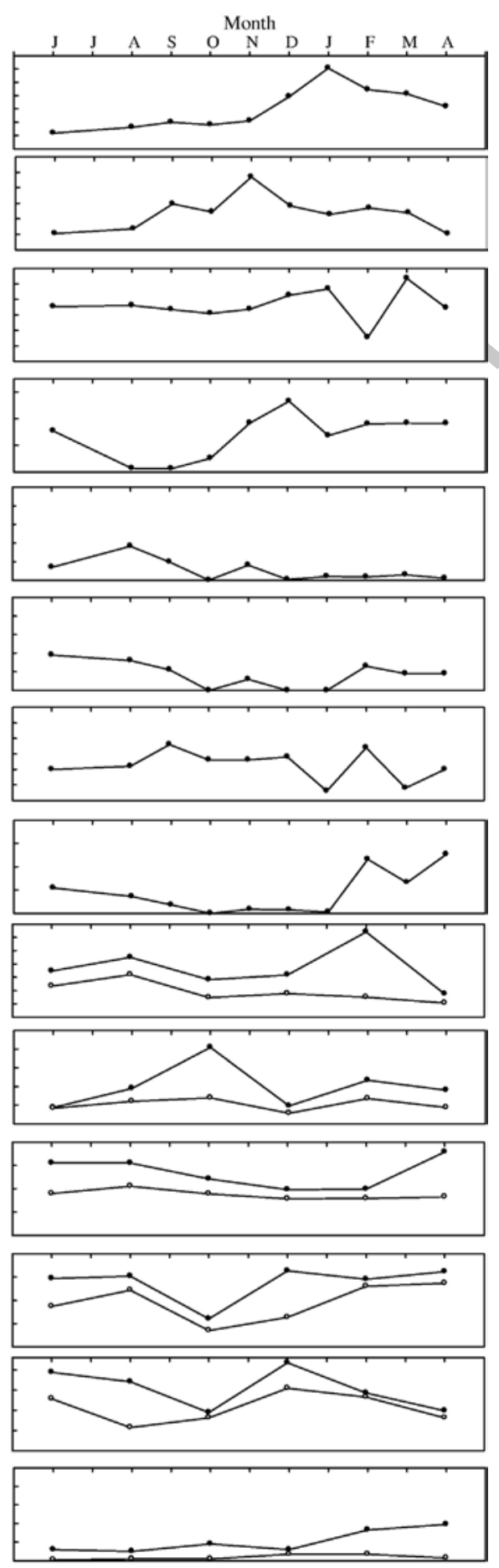

Fig. 3. Surface temporal variability of parameters measured at both Mejillones Bay stations during 2002-2003. Temperature in degrees Celsius; dissolved oxygen in $\mathrm{ml} \mathrm{l}^{-1}$; chlorophyll- $a$ in $\mu \mathrm{g} 1^{-1}$; nutrients in $\mu \mathrm{mol} \mathrm{l}^{-1}$; metals in $\mu \mathrm{g} 1^{-1}$. Black circle is total metal and white circle is dissolved metal. Arrows indicates satellite image dates (See Fig. 4). 
concentrations year-round (Fig. 3). Martín and Fitzwater (1988) have shown that phytoplankton growth is limited by iron availability, especially in the California and Humboldt Current Systems (Hutchins and Bruland, 1998). However, the lack of correlation between Fe and nutrients and chlorophyll would to indicate that this metal has no relationship with biological factors, at least in this bay. By other hand, Des Combes et al. (1999) indicate that the supply of this metal is governed, principally, by continental input probably in the same way as $\mathrm{Mn}$ in Mejillones Bay. However, no significant correlation was found between Fe and Mn (Table 2). In the California Current Johnson et al. (1999) found that $\mathrm{Fe}$ was introduced by resuspended bottom sediment during coastal upwelling. A similar mechanism should be acting in Mejillones bay, because the microxic condition of bottom environments (Valdés, 2004) and the persistence of the upwelling should to introduce Fe into the bay from offshore zone.

\subsubsection{Nickel}

$\mathrm{Ni}$ occurs in oxic waters as $\mathrm{Ni}^{2+}$ and $\mathrm{NiCl}^{+}$(Calvert and Pedersen, 1993). At the Mejillones Bay coastal station, total $\mathrm{Ni}$ was constant during the entire study period, whereas its dissolved form showed high concentrations during winter and low concentrations during spring-summer. The pelagic station registered a highly variable Ni concentrations, with decay during October and high concentrations before and after this month (Fig. 3). The distribution of $\mathrm{Ni}$ is strongly mediated biologically (Kremling, 1985), and its behavior as a micronutrient indicates that it is removed from surface waters by plankton growth (Saager et al., 1992; Morley et al., 1993). It seems like lowest dissolved Ni concentration at station A should be accompanied by a high chlorophyll concentration (Fig. 3), which suggest some influence of biological productivity on $\mathrm{Ni}$ behavior.

\subsubsection{Molybdenum}

Molybdenum (VI) appears in the stable oxidation state in oxic waters and is found as $\mathrm{MoO}_{4}^{2-}$ (Morford and Emerson, 1999; Russell and Morford, 2001; Nameroff et al., 2002). Mo is a conservative metal only affected by physical-chemical factors (Libes, 1992; Brown et al., 1994; Adelson et al., 2001). Because of its conservative nature, it is possible to assume that coastal surface circulation controls the Mo distribution in Mejillones Bay surface waters. Concentrations of dissolved and total Mo were less variable at the coastal than at the pelagic station (Fig. 3), which is closer than upwelling cell (Fig. 1). During warm season the upwelling events are more frequent and intense 395 (Marín et al., 2003), which influence the onshore 396 advection and probably the Mo content in surface 397 waters principally in the pelagic station.

398

\subsubsection{Cadmium}

399

Of all metals measured in this study, $\mathrm{Cd}$ had the 400 lowest concentration. The total concentration presented 401 a more marked variability than its dissolved form at both 402 stations (Fig. 3), as a consequence of the variation of 403 particulate $\mathrm{Cd}$ in Mejillones Bay surface waters. The 404 typical oceanic $\mathrm{Cd}$ distribution presents low or depleted 405 values near the surface (Delgadillo-Hinojosa et al., 406 2001) and is regulated by marine biogeochemical pro- 407 cesses, namely uptake by phytoplankton in surface 408 waters (Abe, 2001). Cd is a nutrient-like metal that 409 presents only one oxidation state in seawater (Cd II) and 410 is found as $\mathrm{CdCl}^{+}$(Morford and Emerson, 1999; Russell 411 and Morford, 2001; Nameroff et al., 2002). This 412 behavior indicates that $\mathrm{Cd}$ has a short residence in 413 surface waters because it is removed rapidly by plankton 414 growth (Calvert and Pedersen, 1993). Temporal Cd 415 variations were associated with chlorophyll- $a$ concen- 416 tration and temperature fluctuation, suggesting that 417 phytoplanktonic biomass production is the principal 418 factor controlling Cadmium concentration in surface 419 waters of Mejillones bay. However, the two highest total 420 Cd values measured in December and April in station A 421 seem too high to be attributed to phytoplankton, because 422 according to Cullen and Sherrell (1999) in a work 423 developed in California Current, the Cd content of 424 marine particles is less than $10 \mathrm{ng}^{-1}$. It is possible that 425 upwelled waters transported by onshore advection have 426 some degree of influence in Cd content in Mejillones 427 bay, as account in others coastal environments (Boyle, 428 1988; Van Geen et al., 1992; Van Geen and Husby, 429 1996; Takesue et al., 2004).

\subsection{Factors controlling seasonal variability of trace 431 metals in Mejillones bay

One possible source of trace metals in Mejillones 433 Bay is the input of lithogenic material. However, Valdés 434 et al. (2000) and Valdés (2004) compared V, Ni, Mo, and 435 $\mathrm{Cd}$ with aluminum (a marker of lithogenic sources 436 according to Dean et al. (1997) in marine sediments, 437 without finding any significant correlations). The 438 authors concluded that continental input in the sedi- 439 ments of Mejillones Bay is not the principal source of 440 these trace metals. Moreover, Vargas et al. (2004) in- 441 dicated that lithogenic debris in the bottom marine 442 sediments of Mejillones Bay represents less than 5\% of 443 

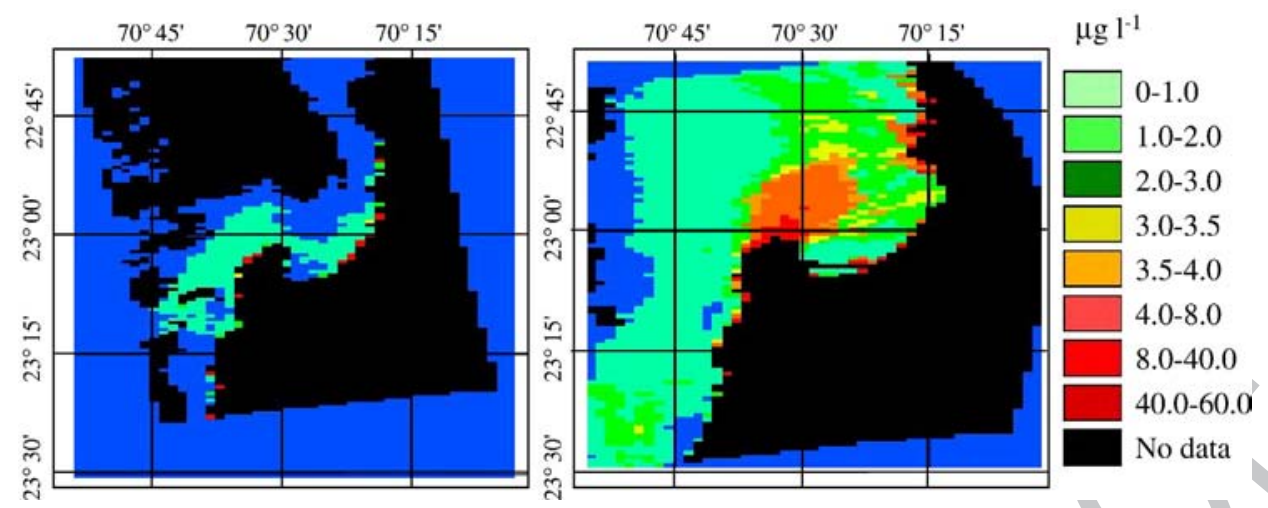

Fig. 4. Satellite image of chlorophyll- $a$ in Punta Angamos upwelling system during August 2002 (left) and March 2003 (right).

the total bulk sediments, which suggests that metals in lithogenic minerals transported from the continent to the ocean constitute a minor source in this coastal area. By other hand, Valdés et al. (2005) demonstrated that contamination doesn't explain the concentration of these trace metals in this bay. However, some influence of waste water treatment plant effluent should be considered specially in station A. Even if influenced to some extent by atmospheric inputs and/or contamination processes in the surface waters, the distribution of $\mathrm{V}$, $\mathrm{Ni}, \mathrm{Cd}$, and Mo in Mejillones Bay at the moment of sampling, can be broadly and principally accounted by a combination of natural oceanic processes and mechanisms.

Seasonal variability was described by grouping parameters into two general annual periods: the cold (autumn-winter) and warm (spring-summer) seasons. Fig. 4 shows typical satellite images (from EOS Aqua Spacecraft; second and third order polynomic correction process) of chlorophyll- $a$ distribution during the cold period (August 28, 2002) and the warm period (February 28, 2003), coincident with the sampling of metals in surface waters. During the cold season low levels of chlorophyll were found in the surface waters of the Punta Angamos upwelling cell and Mejillones Bay (in accordance with chlorophyll measured in situ), which indicated that productivity was low during this period. On the other hand, during the warm season, well productive waters are common, with a filament of high levels of chlorophyll displaced to the north-east, generating an upwelling shadow system (UPS) in the bay, as proposed by Marín et al. (2003). Low levels of dissolved oxygen and high levels of phosphate registered during warm season, particularly in February, are characteristic of upwelling events (Fahrbach et al., 1980).

The lack of a similar pattern of temporal variability of metals in both sampling stations seems to be the most important characteristic. This situation could indicate 481 that there is a combination of factors with different 482 temporal variation patterns which influence the presence 483 of metals in surface waters. Based on the area's oceanic 484 characteristics and the results obtained in this study, a 485 conceptual two-box model is proposed to explain the 486 variation of metals in surface waters of this coastal 487 ecosystem (Fig. 5). The two-box model considered in 488 this work was based on the area's UPS interpretation 489 proposed by Marín et al. (2003), which separates the 490 Mejillones Bay from the Punta Angamos upwelling 491 system. The upwelling event of Punta Angamos causes 492 a biological productivity increment into Mejillones bay, 493 and the development of an efficient retention zone of 494 phytoplanktonic organisms (Marin and Olivares, 1999; 495 Escribano et al., 2000). These characteristics are 496 modulated by the "upwelling shadow" condition present 497 in this bay, which is defined as a confined zone of an 498

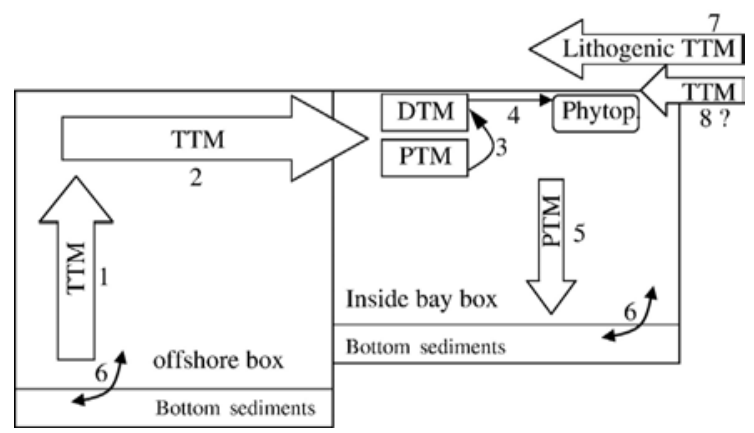

Fig. 5. Conceptual scheme of mechanisms which influence temporal variability of trace metal concentrations in surface waters of Mejillones Bay. $\mathrm{TTM}=$ Total Trace Metal; $\mathrm{PTM}=$ Particulate Trace Metal; DTM = Dissolved Trace Metal; 1 = offshore deep water upwelling; 2 = onshore advection; $3=$ desorption of particulate metals; $4=$ phytoplankton uptake; 5 = scavenging; 6 = exchange at sediment-water interface $7=$ wind transport; $8=$ expected anthropogenic input. 
active coastal upwelling system, whiting which upwelling is less intense (Marin et al., 2001). According to this situation the upwelled waters are transported inside the bay by onshore advection. The upwelling condition founded inside the bay in February, according to PO4 and dissolved oxygen (Fig. 3) represents the spin-up phase of the develop of the upwelling shadow (Marín et al., 2001).

Several studies have shown that coastal surface waters contain higher concentrations of dissolved trace metals (DTM) than open ocean waters (Kremling and Hydes, 1988; Kremling and Pohl, 1989; Muller et al., 1994; Cotté, 1997; Le Gall et al., 1999). The offshore box presents two ways of metal transport: surface circulation entering and vertical circulation via the upwelling of deep water, which results in different intensities depending on the wind direction and strength (Strub et al., 1998). Both mechanisms transport water masses with a much defined chemical composition (metals included). For example, in the case of DTM, at a global scale, Martín and Thomas (1994) estimated that the oceanic input would dominate sources for the oceanic margin. Unfortunately, information about the metal composition of marine waters in the Humboldt system is lacking and it was not possible to compare our results with other works. In the inside the bay box, surface metal concentrations result from very low lithogenic input, uncertain industrial contamination processes (a continuing possibility), ingestion by phytoplankton, desorption from particles, and scavenging due to high organic matter production. In this last case, Bacon and Anderson (1982) propose the "reversible scavenging model", in which the settling and regeneration of biogenic particles are important factors in removing trace metals from surface waters in the ocean. These factors are combined with surface water masses present inside the bay. During period of study the water column of Mejillones bay showed a mixture of Subtropical Surface Water (STSW), Subantarctic Surface Water (SASW), and Equatorial Subsurface Water (ESSW), which are commonly observed offshore of Mejillones Bay (Sobarzo and Figueroa, 2001). Considering that the bay have less than $100 \mathrm{~m}$ deep, it is convenient to talk about the types of water associated to these water masses. Their original properties are modified by a mixture of processes, and/or due to the atmospheric conditions. The composition of these surface water masses has a temporal and spatial variability that is subject to seasonal atmospheric variations such as solar radiation, wind intensity and a mixture of effects caused by the bay's dynamics and coastal upwelling processes. The features of the water-mass core defined in the oceanographic literature do not correspond to the 551 bay's interior. However, it is possible to recognize these 552 traits in spite of the water mixture. In general terms, it 553 can be said that there is a predominance of the STSW at 554 the surface level. However, this level is also character- 555 ized by minimum salinities related to the minimum 556 salinity water levels (MSW) mentioned at Sobarzo and 557 Figueroa's(2001) work corresponding to some type of 558 SASW. This situation should have an important 559 influence on surface distribution of trace metals and 560 can explain the high spatial and temporal variability 561 observed in most of the metals analyzed in this work. 562

Due to the fact that vertical mixing of water column 563 is an important characteristic in Mejillones bay, another 564 factor that should be considered is the influence of 565 microxic condition of subsurface waters (Valdés, 2004), 566 because all the metals analyzed in this work are redox- 567 sensitive (Morford and Emerson, 1999; Bostick et al., 568 2000; Brown et al., 2000, Crusius and Thomson, 2000; 569 Hammond et al., 2000; Zheng et al., 2000, Morford 570 et al., 2001; Russell and Morford, 2001). In the shallow 571 zone (between $0 \mathrm{~m}$ and $45 \mathrm{~m}$ water depth) sediments are 572 deposited under oxic condition. In this zone $\mathrm{Ni}, \mathrm{V}, \mathrm{Cd} 573$ and $\mathrm{Mo}$ are resolubilized during the diagenetic process 574 remaining in solution, while $\mathrm{Mn}$ and Fe precipitate to 575 the sediments. Hatje et al. (2001) suggest that Fe is 576 oxidized faster than $\mathrm{Mn}$ in natural systems, which 577 indicates that $\mathrm{Mn}$ could be transported further away 578 from coast before precipiting in the bottom sediments. 579 In the deeper zone of Mejillones bay prevails a 580 microxic/anoxic sediment-water interface condition 581 which promotes precipitation of Ni, Cd, Mo and V. Fe 582 and $\mathrm{Mn}$ remain in solution and are resolubilized during 583 the diagenetic process.

The combination of these mechanisms and temporal 585 variation could explain the complex behavior of these 586 metals in this upwelling system of northern Chile. $\quad 587$

\section{Conclusions}

588

The temporal distribution of some metals in the 589 coastal waters of the northern Humboldt Current 590 (Mejillones Bay, Chile) has been described in relation 591 to physical-chemical and biological processes.

In Mejillones Bay, nutrients are present year-round in 593 surface waters and are not a limiting factor for high 594 primary productivity. Radiation could be a limiting 595 factor explaining the opposing trend of nutrients and 596 chlorophyll; low radiation in autumn and winter cor- 597 responds to high nutrients and low chlorophyll, whereas 598 high radiation in spring and summer corresponds to low 599 nutrients and high chlorophyll.
600 
The surface concentration of metals does not appear to be explained by anthropogenic inputs (at least not during the year of this work), and variability observed in this study appears to be natural. The lack of correlation between physical-chemical parameters and metals could indicate a more complex combination of factors acting on surface concentrations. It is possible, also, that the temporal variability of metals corresponds to a time scale other than those considered in this study. However, although not significant, a more intense variability in metal concentrations was observed at the pelagic station, which is under the direct influence of the Punta Angamos upwelling cell located off Mejillones Bay.

A two-box conceptual model is proposed to explain the variation of metals in surface waters of this coastal ecosystem. In the offshore box, surface circulation and deep water upwelling transport water masses with different metal contents and different temporal frequencies into the bay. In the inside the bay box, surface metal concentrations result from very low lithogenic input, ingestion by phytoplankton, desorption, and scavenging due to high organic matter production. The development of upwelling events in this area during the sampling period had different effects on each metals and sampling point. Moreover, the mixture of water masses and the Oxygen Minimum Zone which characterize the Mejillones bay should have an important influence on surface distribution of trace metals and can explain the high temporal variability observed in most of the metals analyzed in this work.

\section{Uncited References}

Abe and Matsumaga, 1988

Martín and Knauer, 1984

Segovia-Zavala et al., 1998

Takesue and Van Geen, 2002

\section{Acknowledgements}

This study was supported by grant PEI 1340-02, from the Universidad de Antofagasta, Chile, and UR 055 PALEOTROPIQUE, IRD, France. Support was also provided by IRD through the JEAI (Jeune Equipe Associée à l'IRD) program. We thank Freddy Rabasté and Keyla Majluf for their help in sampling and analytical support in nutrient and chlorophyll determinations. Special thanks to anonymous reviewers for their comments and significantly improving the manuscript.

\section{References}

Abe, K., 2001. Cd in the western equatorial Pacific. Marine Chemistry 650 74, 197-211.

Abe, K., Matsumaga, K., 1988. Mechanism controlling $\mathrm{Cd}$ and $\mathrm{PO}_{4} 652$ concentration in Funka Bay, Japan. Marine Chemistry 23, 653 145-152.

Adelson, J., Helz, G., Miller, C., 2001. Reconstructing the rise of 655 recent coastal anoxia; molybdenum in Chesapeake bay sediments. 656 Geochimica et Cosmochimica Acta 65 (2), 237-252.

Bacon, M., Anderson, R., 1982. Distribution of thorium isotopes 658 between dissolved and particulate forms in the deep sea. Journal of 659 Geophysical Research 83, 2045-2056.

Bostick, B., Fendorf, S., Fendorf, M., 2000. Disulfide disproportion- 661 ation and $\mathrm{CdS}$ formation upon cadmium sorption on $\mathrm{FeS}_{2} .662$ Geochemica et Cosmochemica Acta 64 (2), 247-255. 663

Brown, J., Colling, A., Park, D., Phillips, J., Rothery D., Wright J., 664 1994. Ocean Chemistry and Deep-Sea sediments. The Open 665 University/Pergamon Eds. Oxford, Great Britain: 133 pp. 666

Brown, E., Callonec, L., German, Ch., 2000. Geochemical cycling of 667 redox-sensitive metals in sediments from lake Malawi: a diagnostic 668 paleotracer for episodic changes in mixing depth. Geochimica et 669 Cosmochimica Acta 64 (20), 3515-3523.

Bruland, K., 1983. Trace elements in sea-water. In: Riley, J.P., Chester, R. 671 (Eds.), Chemical Oceanography, vol. 8. Academic Press, London, 672 pp. $157-220$.

Calvert, S., Pedersen, T., 1993. Geochemistry of recent oxic and 674 anoxic marine sediments: implications for the geological records. 675 Marine Geology 11, 67-88.

676

Cotté M. 1997. Origines et comportement des métaux disous dans les 677 eaux de la marge Atlantique Européenne. PhD Thesis, University 678 of Paris VI, 210 pp.

Cotte-Krief, M., Guieu, C., Thomas, A., Martin, J., 2000. Sources of 680 $\mathrm{Cd}, \mathrm{Cu}, \mathrm{Ni}$ and $\mathrm{Zn}$ in the Portuguese coastal waters. Marine 681 Chemistry 71, 199-214.

Crusius, J., Thomson, J., 2000. Comparative behavior of authigenic 683 $\mathrm{Re}, \mathrm{U}$, and Mo during reoxidation and subsequent long-term burial 684 in marine sediments. Geochimica et Cosmochimica Acta 64 (13), 685 2233-2242.

Cullen, J., Sherrell, R., 1999. Techniques for determination of trace 687 metals in small samples of size-fractioned particulate matter: 688 phytoplankton metals off central California. Marine Geology 67, 689 233-247.

Dean, W., Gardner, J., Piper, D., 1997. Inorganic geochemical indicators 691 of glacial-interglacial changes in productivity and anoxia on the 692 California continental margin. Geochimica et Cosmochimica Acta 61693 (21), 4507-4518.

Delgadillo-Hinojosa, F., Macías-Zamorano, J., Segovia-Zavala, J., 695 Torres-Valdés, S., 2001. Cadmium enrichment in the Gulf of 696 California. Marine Chemistry 75, 109-122.

Des Combes, H., Caulet, J., Tribovillard, N., 1999. Pelagic 698 productivity changes in the equatorial area of the northwest 699 Indian Ocean during the last 400,000 years. Marine Geology 15, 700 $27-55$.

Escribano, R., Rodriguez, L., Irribarren, C., 1998. Temperature- 702 dependent development and growth of Calanus chilensis Brodsky 703 from northern Chile. Journal of Experimental Marine Biology and 704 Ecology 229, 19-34.

Escribano, R., Rosales, S., Blanco, J., 2004. Understanding upwelling 706 circulation off Antofagasta (northern Chile): a three-dimensional 707 numerical-modeling approach. Continental Shelf Research 24, 708 $37-53$. 
Fahrbach, E., Brockman, C., Lostanau, N., Urquizo, W., 1980. The northern peruvian upwelling system during the ESACAN experiment. In: Richards, F. (Ed.), Coastal Upwelling, Coastal and Estuarine Science. AGU, Washington D.C., pp. 134-145.

Gonzalez, H., Daneri, G., Figueroa, D., Iriarte, J., Lefevre, N., Pizarro, G., Quiñónez, R., Sobarzo, M., Troncoso, A., 1998. Producción Primaria y su destino en la trama trófica pelágica y océano profundo e intercambio océano-atmósfera de $\mathrm{CO} 2$ en la zona norte de la corriente de Humboldt $\left(23^{\circ} \mathrm{S}\right)$ : posibles efectos del evento El Niño, 1997-98 en Chile. Revista Chilena de Historia Natural 71, $429-458$

Gonzalez, H., Ortiz, V., Sobarzo, M., 2000. The role of faecal material in the particulate organic carbon flux in the northern Humboldt Current, Chile (23 S), before and during the 1997-1998 El Niño. Journal of Plankton Research 22 (3), 499-529.

Gonzalez-Davila, H., 1995. The role of phytoplankton cells on the control of heavy metals concentrations in seawater. Marine Chemistry $48,215-236$.

Gonzalez, H., Giesecke, R., Vargas, C., Pavez, M., Iriarte, J., Santibáñez, P., Castro, L., Escribano, R., Pagés, F., 2004. Carbon cycling through the pelagic foodweb in the northern Humboldt Current off Chile $\left(23^{\circ} \mathrm{S}\right)$. Journal of Marine Science 61, 572-584.

Grotti, M., Soggia, F., Abelmoschi, M., Rivaro, P., Magi, E., Frache, R., 2001. Temporal distribution of trace metals in Antarctic coastal waters. Marine Chemistry 76, 189-209.

Hammond, D., Mcmanus, J., Berenson, W., Meredith, Ch., Klinkhammer, G., Coale, K., 2000. Diagenetic fractionation of Ge and $\mathrm{Si}$ in reducing sediments: the missing Ge sink and a possible mechanism to cause glacial/interglacial variations in oceanic Ge/ Si. Geochimica et Cosmochimica Acta 64 (14), 2453-2465.

Hatje, V., Birch, G., Hill, M., 2001. Spatial variability of particulate trace metals in Port Jackson Estuary, Australia. Estuarine, Coastal and Shelf Science 53, 62-77.

Holm-Hansen, O., Lorenzen, C., Holmes, R., Strickland, J., 1965. Fluorometric determination of chlorophyll. Journal du Conseil - Conseil Permanent International pour l'exploration de la Mer 30, 3.15.

Hutchins, D., Bruland, K., 1998. Iron-limited diatom growth and Si:N uptake ratios in a coastal upwelling regime. Nature $393,561-564$.

Iriarte, J., Gonzalez, H., 2004. Phytoplankton size structure during and after the 1997/1998 El Niño in coastal upwelling area of the northern Humboldt Current System. Marine Ecology Progress Series 269, 83-90.

Iriarte, J., Pizarro, G., Troncoso, V., Sobarzo, M., 2000. Primary production and biomass of size-fractioned phytoplankton of Antofagasta, Chile $\left(23-24^{\circ} \mathrm{S}\right)$ during pre-El Niño and El Niño 1997. Journal of Marine Systems 26, 37-51.

Johnson, K., Chavez, F., Friedrich, G., 1999. Continental-shelf sediments as a primary source of iron for coastal phytoplankton. Nature 398, 697-700.

Kremling, K., 1985. The distribution of cadmium, copper, nickel, manganese, and aluminum in surface waters of the open Atlantic and European shelf area. Deep-Sea Research 32 (5), 531-555.

Kremling, K., Hydes, D., 1988. Summer distribution of dissolved Al, $\mathrm{Cd}, \mathrm{Cu}, \mathrm{Mn}$, and $\mathrm{Ni}$ in the surface waters around the British Isles. Continental Shelf Research 8, 89-105.

Kremling, K., Pohl, C., 1989. Studies on the spatial and seasonal variability of dissolved cadmium, copper and nickel in the Northeast Atlantic surface waters. Marine Chemistry 27, 43-60.

Le Gall, A., Hydes, D., Statham, P., Morley, H., Hunt, C., 1999. Processes influencing distribution and concentration of $\mathrm{Cd}, \mathrm{Cu}$, $\mathrm{Mn}$ and $\mathrm{Ni}$ at the North West European shelf breaks. Marine Chemistry 68, 97-115.
Libes, S., 1992. An Introduction to Marine Biogeochemistry. John 772 Wiley \& Sons, Inc., pp. 15-190.

Marín, V., Olivares, G., 1999. Estacionalidad de la productividad 774 primaria en bahía Mejillones del Sur (Chile): una aproximación 775 proceso-funcional. Revista Chilena de Historia Natural 72, 776 629-641.

Marín, V., Escribano, R., Delgado, L., Olivares, G., Hidalgo, P., 2001. 778 Nearshore circulation in a coastal upwelling site off the northern 779 Humboldt Current System. Continental Shelf Research 21, 780 $1317-1329$.

Marín, V., Delgado, L., Escribano, R., 2003. Upwelling shadows at 782 Mejillones bay (northern Chilean coast): a remote sensing in situ 783 análisis. Investigaciones Marinas 31 (2), 47-55. 784

Martín, J., Knauer, G., 1984. Manganese transport through oxygen 785 minima. Earth and Planet Science Letters 67, 35-47. 786

Martín, J., Fitzwater, S., 1988. Iron deficiency limits phytoplankton 787 growth in the north-east Pacific subartic. Nature 331, 341-343. 788

Martín, J., Thomas, A., 1994. The global insignificance of telluric 789 input of dissolved trace metals $(\mathrm{Cd}, \mathrm{Cu}, \mathrm{Ni}$ and Zinc) to ocean 790 margin. Marine Chemistry 46, 165-178.

791

Morford, J., Emerson, S., 1999. The geochemistry of redox-sensitive 792 trace metals in sediments. Geochimica et Cosmochimica Acta 63793 (11/12), 1735-1750.

794

Morford, J., Russell, A., Emerson, S., 2001. Trace metal evidence for 795 changes in the redox environment associated with the transition 796 from terrigenous clay to diatomaceous sediment, Saanich Inlet, 797 BC. Marine Geology 174, 355-369.

798

Morley, N., Statham, P., Burton, J., 1993. Dissolved trace metals 799 in the southwestern Indian Ocean. Deep-Sea Research 40 (5), 800 $1043-1062$.

801

Muller, F., Tranter, M., Balls, P., 1994. Distribution and transport of 802 chemical constituents in the Clyde Estuary. Estuarine, Coastal and 803 Shelf Science 39, 105-126.

804

Nameroff, T., Balistrieri, L., Murray, W., 2002. Suboxic trace metals 805 geochemistry in the eastern tropical North Pacific. Geochimica et 806 Cosmochimica Acta 66 (7), 1139-1158.

Ortlieb, L., Escribano, R., Follegati, R., Zúñiga, O., Kong, I., 808 Rodríguez, L., Valdes, J., Guzmán, N., Iratchet, P., 2000. Ocean- 809 climatic changes during the last 2,000 years in a hypoxic marine 810 environment of Northern Chile (23 ${ }^{\circ}$ S). Revista Chilena de 811 Historia Natural 73, 221-242.

Parsons, T., Maita, Y., Lalli, C., 1984. A Manual of Chemical and 813 Biological Methods Seawaters Analysis. Pergamon Press, Oxford, 814 United Kingdom, p. 173.

815

Pizarro, G., Iriarte, J., Montecinos, V., 2002. Mesoscale primary 816 production and bio-optical variability off Antofagasta $\left(23^{\circ}-24^{\circ} \mathrm{S}\right) 817$ during the transition to El Niño 1997-1998. Revista Chilena de 818 Historia Natural 75, 201-215.

Rodriguez, L., Marin, V., Farias, M., Oyarce, E., 1991. Identification 820 of an upwelling zone by remote sensing and in situ measurement. 821 Mejillones del Sur Bay (Antofagasta-Chile). Scientia Marina 55822 (3), 467-473.

Román, D., Rivera, L., Morales, T., Ávila, J., Cortés, P., 2003. 824 Determination of trace elements in environmental and biological 825 samples using improved simple introduction in flame absorption 826 spectrometry (HHPN-AAS; HHPN-FF-AAS). International Jour- 827 nal of Environmental Analytical Chemistry 83, 327-341. 828

Russell, A., Morford, J., 2001. The behavior of redox-sensitive metals 829 across a laminates-massive-laminated transition in Saanich Inlet, 830 British Columbia. Marine Geology 174, 341-354. 831

Saager, P., De Baarm, H., Howland, R., 1992. Cd, Zn, Ni and Cu in the 832 Indian Ocean. Deep-Sea Research 39 (1), 9-35. 
Schenau, S., Reichart, G., De Lange, G., 2002. Oxygen minimum zone controlled Mn redistribution in Arabian Sea sediments during the late Quaternary. Paleoceanography 17 (4), 10-1-10-12.

Segovia-Zavala, J., Delgadillo-Hinojosa, F., Alvarez-Borrego, S., 1998. Cadmium in the coastal upwelling area adjacent to the California-Mexico border. Estuarine, Coastal and Shelf Science 46, 475-781.

Sobarzo, M., Figueroa, D., 2001. The physical structure of a cold filament in a Chilean upwelling zone (Peninsula de Mejillones, Chile, $\left.23^{\circ} \mathrm{S}\right)$. Deep-Sea Research 48, 2699-2726.

Strub, P., Mesias, J., Montecinos, V., Rutllant, J., Marchant, S., 1998. Coastal oceanic circulation off western South America. In: Robinson, A., Birnk, K. (Eds.), The Sea. John Wiley, New York, USA, pp. 273-314.

Takesue, R., Van Geen, A., 2002. Nearshore circulation during upwelling inferred from the distribution of dissolved cadmium off the Oregon coast. Limnology and Oceanography 47, 176-185.

Takesue, R., Van Geen, A., Carriquiry, J., Ortiz, E., Godinez-Orta, L., Granados, I., Saldivar, M., Ortlieb, L., Escribano, R., Guzmán, N., Castilla, J., Varas, M., Salamanca, M., Figueroa, C., 2004. Influence of coastal upwelling and El Niño-Southern Oscillation on nearshore water along Baja California and Chile: shore-based monitoring during 1997-2000. Journal of Geophysical Research 109, 1-14.

Ulloa, O., Escribano, R., Hormazabal, S., Quiñónez, R., Gonzalez, R., Ramos, R., 2001. Evolution and biological effects of the 1997-98 El Niño in the upwelling ecosystem off northern Chile. Geophysical Research Letters 28, 1591-1594.

Valdés, J., 2004. Evaluación de metales redox-sensitivos como proxies de paleoxigenación en un ambiente marino hipóxico del norte de Chile. Revista Chilena de Historia Natural 77, 121-138.

Valdés, J., Ortlieb, L., 2001. Paleoxigenación subsuperficial de la columna de agua en la bahía Mejillones del Sur $\left(23^{\circ} \mathrm{S}\right)$ : Indicadores geoquímicos en testigos de sedimento marino. Investigaciones Marinas 29 (1), 25-35.
Valdés, J., López, L., Lomónaco, S., Ortlieb, L., 2000. Condiciones 868 paleoambientales de sedimentación y preservación de materia 869 orgánica en Bahía Mejillones del Sur (23ㅇ S), Chile. Biología 870 Marina y Oceanografía. Revista de Biologia Marina y Oceano- 871 grafia 35 (2), 169-180.

Valdés, J., Ortlieb, L., Sifeddine, A., 2003. Variaciones del sistema de 873 surgencia de Punta Angamos (23 S) y la Zona de Mínimo 874 Oxígeno durante el pasado reciente. Una aproximación desde el 875 registro sedimentario de la bahía Mejillones del Sur. Revista 876 Chilena de Historia Natural 76, 347-362. 877

Valdés, J., Sifeddine, A., Lallier-Verges, E., Ortlieb, L., 2004. 878 Petrographic and geochemical study of organic matter in surficial 879 sediments from an upwelling system (Mejillones del Sur bay, 880 northern Chile). Organic Geochemistry 35 (5), 881-894. 881

Valdés, J., Vargas, G., Sifeddine, A., Ortlieb, L., Guiñez, M., 2005. 882 Distribution and enrichment evaluation of heavy metals in 883 Mejillones Bay $\left(23^{\circ} \mathrm{S}\right)$, northern Chile: geochemical and statistical 884 approach. Marine Pollution Bulletin 50, 1558-1568. 885

Van Geen, A., Husby, D., 1996. Cadmium in the California Current 886 System: tracer of the past and present upwelling. Journal of Geo- 887 physical Research 101, 3489-3507. 888

Van Geen, A., Luoma, S., Fuller, C., Anima, R., Clifton, E., Trumbore, 889 S., 1992. Evidence from $\mathrm{Cd} / \mathrm{Ca}$ ratio in foraminifera for greater 890 upwelling off California 4,000 years ago. Nature 358, 54-56. 891

Vargas, G., Ortlieb, L., Pichon, J., Bertaux, J., Pujos, M., 2004. 892 Sedimentary facies and high resolution primary production infer- 893 ences from laminated diatomaceous sediments off northern Chile 894 $\left(23^{\circ} \mathrm{S}\right)$. Marine Geology 211, 79-99. 895

Zheng, Y., Anderson, R., Van Geen, A., Kuwabara, J., 2000. 896 Authigenic molybdenum formation in marine sediments: a link 897 to porewater sulfide in the Santa Barbara basin. Geochimica et 898 Cosmochimica Acta 64, 4165-4178. 